\title{
Final Year Undergraduate Students' Perception of their Non-technical Skills
}

\author{
Olawale Fatoki \\ Department of Business Management, Turfloop Campus, \\ University of Limpopo, Limpopo Province, South Africa \\ E-mail: Olawale.fatoki@ul.ac.za
}

\section{Doi:10.5901/mjss.2014.v5n7p43}

\begin{abstract}
The objective of the study is to investigate the perception of final year undergraduate students about their non-technical skills. The study focussed on the final year students (undergraduate level) in the Department of Business Management of a South African university. Data was collected through the use of self-administered questionnaire in a survey. Data analysis included descriptive statistics and the T-test. The results indicate that students have a favourable perception of their non-technical skills. There is no gender difference in the perception of students. Recommendations to improve non-technical skills of students are suggested.
\end{abstract}

Keywords: undergraduate students, perception, non-technical, skills, South Africa

\section{Introduction}

Graduate unemployment rate is on the increase in South Africa due to lack of job opportunities. According to Van Der Berg and Van Broehuizen (2012), graduate unemployment in South Africa (where 'graduates' are considered to be those with at least university degree) is quite low in an international context. Graduate unemployment has risen extremely modestly even during the current difficult global and domestic economic conditions. City Press (2012) however reports that university degrees or diplomas no longer hold the promise of jobs for young South Africans as hundreds of thousands of them battle to find work. The Economist (2012) points out that there are more than 800,000 vacancies in the private sector alone, despite the fact that 600,000 university graduates are jobless.

Mathabathe (2006) notes that one of the causes of graduate unemployment is the shortfall or mismatch between the skills students develop during their courses and the skills that employers need. Graduates should not only acquire skills, but such skills should also be relevant to changing labour market needs. Grisel and Parker (2009) assert that in South Africa, there is a common misunderstanding between higher education and the work place about the role of each other. Employers complain about the quality of university graduates. Higher education however feels that employers are not fully appreciative of the qualities and skills graduate possess.

According to Hancock et al. (2009), the skills learned by students during their academic career can be placed into the two broad skill categories: (1) Technical and (2) Non-technical. Technical skills refer to subject-specific or contentspecific knowledge and competence that are relevant to a particular discipline. Non-technical skills are those skills which are relevant across many different jobs or professions. Non-technical skills are typically not job specific. They are generic to a range of different work contexts. Jackson and Chapman (2012) point out that today's employers often require new graduates to add immediate value. Thus, undergraduates must develop both technical and non-technical skills to achieve this goal. The development of only technical skills is no longer considered sufficient for graduates. Du Pre and Williams (2011) concur that the most effective way for graduates to stand out among the crowd is to prove that they possess outstanding credentials in a number of non-industry specific desired skill areas.

Schultz (2008) and Wilson et al. (2012) agree that to be successful in the tough environment, candidates for jobs must distinguish themselves from other candidates with similar qualifications. It is no longer sufficient for new graduates to have knowledge of an academic subject. Jarvis (2000) argues that universities must prepare and equip graduates with entry-level knowledge and skills for the labour market. In addition, universities must equip graduates with the ability to play a leadership role as a custodian of knowledge.

Studies on the non-technical skills of university students can be approached from the employers' perspective (Griesel and Parker, 2009); Jackson and Hancock, 2010) or students' perspective (Symiington, 2012). This study aims to investigate how final year undergraduate students perceive their non-technical skills. Smith and Bath (2006) and 
Devadason (2010) point out that there is a growing realisation among researchers that students' point of view is important in education research. Students' point of view provides a credible source of information on what students have gained from their educational experiences.

\section{Objective of the Study}

Non-technical skills are highly important to graduate employability. Today's employers require new graduates to add immediate value. The development of only technical skills is no longer considered sufficient for graduates in the highly competitive labour market. Thus, undergraduates must develop both technical and non-technical skills. The objective of the study is to investigate the perception of final year undergraduate students about their non-technical skills.

\section{Literature Review}

According to Pfeffer and Salancik (1978), the Resource Dependency Theory argues that resources are a critical or important part of an organisation's operation. Resources can be tangible, intangible and human relate. Human related resources include technical and non-technical skills (Huang, 2010). Mack and Media (2014) describe technical skills as skills that reflect specific practical knowledge. Technical skills apply to specific job requirements. Non-technical skills refer to a general ability to perform professionally within an organisation. Non-technical skills include the ability to lead, work well with others, communicate thoughts clearly, negotiate business deals, mentor others, manage time well, display a professional image and interact well with clients, Basic communication skills, such as the ability to write and speak effectively, are also important non-technical skills. Both types of skill sets are important for success. According to Nasir et al (2012), technical skills are basic knowledge to any work in any industry. A technical skill by definition is the knowledge of and proficiency in certain specialized field. Awang et al. (2006) note that non-technical skills refer to skills that are not specific to any particular job position or workplace environment, but can be used widely in all jobs and tasks assigned.

Nasir et al. (2012) point out that non-technical skills, also called generic skills, basic skills, soft skills, employability skills, key skills, core skills and essential skills. According to Conrad and Leigh (1999), non-technical skills can be put into four categories: problem solving and other cognitive skills; oral communication skills; personal qualities and work ethic; and interpersonal and teamwork skills. Gibb (2003) classifies non-technical skills into (1) basic/fundamental skills (2) people-related skills (3) conceptual/thinking skills. (4) personal skills and attributes (5) business skills and (6) community skills. Awang et al. (2006) and Nasir et al. (2011) note that non-technical skills can be divided into two categories: functional and adaptive. Functional skills are basic skills used to apply to tasks and to solve new problems. Functional skills include communicating, questioning, analyzing and decision-making. Adaptive skills are skills that describe the manner in which employees conduct themselves and interact with the working environment. Adaptive skills include teamwork skills and leadership and organizational skills. Wilson et al. (2012) point out that non-technical skills comprise of seven skills. These are communication skills, critical thinking and problem-solving skills, team work skills; lifelong learning and information management skills, entrepreneurial skills, moral and professional ethics and leadership skills.

According to Howieson (2003), the increased demand by employers for non-technical skills from students can be attributed to three factors. These are (1) changing attitudes of the perceived role of higher education; (2) changes in business practices and (3) changes in job roles. Jackson and Hancock (2010) point out that the development of discipline-specific skills and knowledge is no longer considered sufficient for graduates. Universities are becoming increasingly responsible for the development of a generic skill set deemed essential in undergraduates. Nasir et al. (2011) assert that the quality of skilled workers is evaluated through their technical skills and non-technical skills. Technical skill alone is not enough to survive in the ever-changing business environment. According to Nasir et al. (2011), the rapid increase of technology has contributed to increased demands on skilled workers to possess both technical and non-technical skills.

\section{Research Methodology}

The study focused on the final year students (undergraduate level) in the Department of Business Management at a selected University located in the Limpopo Province of South Africa. The student population is 249. Raosoft sample size calculator gave a sample size of 152. However, 200 questionnaires were distributed in class to the students with the assistance of the lecturer. Data was collected through the use of self-administered questionnaire in a survey. The questionnaire was developed by the author through a review of the literature on non-technical skills. The questionnaire included questions on four areas of non-technical skills. These are basic skills, people skills, conceptual skills and 
personal skills and traits. To measure students' perception of their non-technical skills, the five-point Likert scale ranging from "1 extremely poor, 2 below average, 3 average, 4 above average and 5 excellent" was used. The study used descriptive statistics (mean and standard deviation) and the T-test for data analysis.

\section{Results and Discussion}

200 were distributed and 182 returned. The response rate was 91\%. 13 questionnaires were found unusable. 169 questionnaires were found usable. 73 respondents were male and 96 were female.

Table 1: Responses on non-technical skills

\begin{tabular}{|l|c|c|}
\hline Skills & Mean & Standard deviation \\
\hline Basic skills & & \\
\hline Oral communication skill (speaking, listening) & 4.67 & 1.253 \\
\hline Reading skill & 4.69 & 1.124 \\
\hline Writing skill & 4.52 & 1.112 \\
\hline Numeracy and quantitative literacy & 4.22 & 0.985 \\
\hline Computer literacy & 4.35 & 0.966 \\
\hline Ability to use the internet to find and access information & 4.52 & 1.101 \\
\hline People skills & & \\
\hline Communication skill & 4.04 & 1.229 \\
\hline Teamwork skill (ability to work with other people) & 3.96 & 1.018 \\
\hline Inter-personal skill (ability to interact with others) & 4.02 & 1.111 \\
\hline Conceptual skills & & \\
\hline Problem solving skill & 3.96 & 0.953 \\
\hline Creative skill & 3.74 & 0.949 \\
\hline Planning and organising skill & 3.92 & 1.001 \\
\hline Decision making skill & 3.65 & 1.009 \\
\hline Learning to learn skill (ability to follow instructions) & 3.65 & 0.938 \\
\hline Personal skills and traits & & \\
\hline Dependability & 4.55 & 1.205 \\
\hline Responsibility & 4.02 & 1.109 \\
\hline Ability to withstand work pressure & 3.42 & 0.936 \\
\hline Emotional control & 3.45 & 0.921 \\
\hline Positive attitude towards work & 3.62 & 0.906 \\
\hline Time management & 3.54 & 0.935 \\
\hline Self-confidence, positive image & 4.20 & 1.003 \\
\hline Adaptability, flexibility & 3.90 & 0.981 \\
\hline Enthusiasm & 3.74 & 0.973 \\
\hline Self-discipline & 3.65 & 1.018 \\
\hline Honesty, integrity & 4.85 & 1.034 \\
\hline Ability to work without supervision & 4.02 & 0.986 \\
\hline
\end{tabular}

Table 1 depicts the perception of final year undergraduate students about their non-technical skills. Basic skills: the results indicate that students perceive themselves as above average to excellent in the six measures of basic skills. Oral communication has a mean of 4.67 , reading skills 4.69 , writing skills 4.52 , numeracy and quantitative literacy 4.22 , computer literacy, 4.35 and inter-personal (ability to interact with others), 4.02. The results indicate that students have a positive perception of their basic skills. People skills: The means for the three measures of people skills are communication skill 4.04, teamwork skill, 3.96 and inter-personal skill 4.02. The results suggest that students have a positive perception of their people skills. Conceptual skills: The means for the five measures of conceptual skills are problem solving skill 3.96, Creative skill, 3.74, planning and organising skill, 3.92, decision making skill, 3.65 and learning to learn skill (ability to follow instructions) 3.62. The results suggest that students have a positive perception of their conceptual skills. Personal skills and traits: The means for the twelve measures of personal skills and traits range from 3.42 (ability to withstand work pressure to 4.85 for honesty. The results indicate a favourable perception of personal skills and traits. It can be concluded that generally students have a positive perception of their non-technical skills. Comparing the different skills, the results indicate that students perceive themselves to be better in basic skills compared to 
conceptual skills. In addition, the non-technical skill with the lowest mean is ability to work under pressure with a mean of 3.42. The T-test results indicate no gender differences for the four measures of non-technical skills.

\section{Conclusions}

The objective of the study is to investigate the perception of final year undergraduate students about their non-technical skills. Non-technical skills are highly important to graduate employability. Non-technical skills include basic skills, people skills, conceptual skills and personal skills and traits. The results indicate that students have a positive perception of their non-technical skills. The results indicate that students perceive themselves to be better in basic skills compared to conceptual skills. The non-technical skill with the lowest mean is ability to work under pressure. The non-technical skill with the highest mean is honesty and integrity. There is the need for a change in the curriculum to make non-technical skills highly important in university education. University students should go to for practical work training through internship to improve non-technical skills. In view of the constantly changing skill requirements, due to the constantly changing business environment, universities should develop a strong partnership with employers on the skills that they require from graduates. Students should be encouraged to participate in tasks in the university that can improve their leadership and communication skills. Students should be proactive by joining and participating in the activities of student organisations on the campus. This will improve their teamwork and leadership skills. Lecturers should develop formative assessments that focus more on team work rather than individual work.

\section{References}

Akrani, Gaurav, (2014). Managerial Skills - Conceptual, Human Relations and Technical. [Online] Available: http://kalyancity.blogspot.com/2011/06/managerial-skills-conceptual-human.html (January 8, 2014)

Awang Zubaidah, Abidin, Hafilah, Arshad, Razib, Habil, Hadina, Yahya, Ahmad. (2006). non-technical skills for engineers in the 21st century: a basis for developing a guideline. [Online] Available: http://eprints.utm.my/2755/1/74232.pdf (December 5, 2013)

City Press 2012. Young, jobless and desperate. Degrees with no guarantees. [Online] Available: http://www.citypress.co.za/SouthAfrica /News/Young-jobless-and-desperate-Degrees- with-noguarantees-20120616. (August 19, 2013)

Conrad, C. A., Leigh, W., A. (1999). Soft Skills: Bridge or Barrier to Employment? The monthly magazine of the Joint Centre for Political and Economic Studies, 27(1):27-45.

Devadason, E., Subramaniam, T., \& Daniel, E. (2010). Final year undergraduates' perceptions of the integration of soft skills in the formal curriculum: a survey of Malaysian public universities. Asia Pacific Education Review, 11(3), 321-348.

DuPre, C. \& Williams, K. (2011). Undergraduates' Perceptions of Employer Expectations Journal of Career and Technical Education, 26(1): 8-19

Gibb, Jennifer (2003). What impact is implementing a quality system having on the vocational education and training classroom? [Online] Available: http://www.avetra.org.au/abstracts_and_papers/17_gibb.pdf (January 30, 2014)

Griesel, Hanlie, Parker, Ben (2009) A baseline study on South African graduates from the perspective of employers [Online] Available: http://www.saqa.org.za/docs/pubs/general/graduate_attributes.pdf (January 15, 2014).

Jackson, D., \& Hancock. P. () Non-technical Skills in Undergraduate Degrees in Business: Development and Transfer. Education Research and Perspectives, 37(1):57-84.

Jackson, D., Chapman, E. (2012) Non-technical skill gaps in Australian business graduates Education + Training, 54(2/3): 95-113.

Jarvis, P. 2000. The changing university: Meeting a need and needing a change. Higher Education Quarterly, 54(1): 43-67.

Hancock, P., Howieson, B., Kavanagh, M., Kent, J., Sturt, C.,Tempone, I., \& Segal, N. (2009). Accounting for the future: more than numbers. Australian Learning and Teaching Council 1(1):1-80

Howieson, B. (2003) Accounting Practice in the Next Millennium: Is Accounting Education Ready to Meet the Challenge? The British Accounting Review, 35(2) 69-103.

Huang, L.K. (2010). A Resource-based Analysis of IT Personnel Capabilities and Strategic Alignment. Journal of Research and Practice in Information Technology, 42(4): 263-287

Mack, Stan, Media, Demand. (2014). The Difference Between Technical Skills \& Business Skills. [Online] Available: http://smallbusiness.chron.com/difference-between-technical-skills-business-skills-25482.html (January 18, 2014).

Mathabathe O.M (2006) the management of unemployability of graduates in Soshanguve region [Online] Available: http://libserv5.tut.ac.za:7780/pls/eres/wpg_docload.download_file?p_filename=F1326820672/Mathabathe.pdf (January 15, 2014).

Nasir, Ahmad, Ali, Dayana, Noordin, Muhammad, Nordin, Mohd. (2011). Technical skills and non-technical skills: predefinition concept [Online] Available: http://www.ietec-conference.com/ietec11/Conference\%20Proceedings/ietec/papers/Conference\%20Papers \%20Refereed/Monday/MP2/MP2.3_20.pdf (January 11, 2014).

Pfeffer J, Salancik GR 1978. The External Control of Organizations: A Resource Dependence Perspective. New York: Harper and Row.

Schulz, B. (2008). The Importance of Soft Skills: Education beyond academic knowledge. Journal of Language and Communication, (June) $146-154$

Smith, C., \& Bath, D. (2006). The role of the learning community in the development of discipline knowledge and generic graduate 
outcomes. Higher Education, 51, 259-286.

Symington, Nicola (2012). Investigating graduate employability and psychological career resources [Online] Available: http://upetd.up.ac.za/thesis/available/etd-06292012-135746/ (January 18, 2014).

The Economist (2012) Education in South Africa still dysfunctional [Online] Available: http://www.economist.com/node/21543214 (January 15, 2014).

Van der Berg, Servaas, \& Van Broekhuizen, Hendrik, (2012). Graduate unemployment in South Africa: A much exaggerated problem. [Online] Available: http://www.econ3×3.org/article/how-high-graduate-unemployment-south-africa-much-needed-update (May 12, 2013).

Wilson, A.J., Ariffian, B. A., Abu Zarin, H. (2012). The embedment of soft skills in real estate program via coursework. [Online] Available: http://www.internationalconference.com.my/proceeding/icber2012_proceeding/055_220_3rdlCBER2012_Proceeding_PG0831_0 846.pdf ((January 15, 2014). 